Вітомський В.В.

\title{
Аналіз показників терапевтичного альянсу між кардіохірургічними пацієнтами та фізичними терапевтами за результатами анкетування паціснтів
}

\author{
Національний університет фізичного виховання і спорту України, м. Київ, Україна \\ ДУ «Науково-практичний медичний центр дитячої кардіології та кардіохірургії МОЗ України», м. Київ, Україна \\ vitomskiyvova@gmail.com
}

\begin{tabular}{|c|c|}
\hline $\begin{array}{c}\text { Витомский В.В. } \\
\text { Анализ терапевтического альянса } \\
\text { между кардиохирургическими пациентами } \\
\text { и физическими терапевтами по результатам } \\
\text { анкетирования пациентов } \\
\text { Национальный университет } \\
\text { физического воспитания и спорта Украины } \\
\text { ГУ «Научно-практический медицинский центр } \\
\text { детской кардиологии и кардиохирургии МЗ Украины» }\end{array}$ & $\begin{array}{l}\text { Vitomskyi V.V. } \\
\text { Analysis of the indicators of the therapeutic alliance } \\
\text { between cardiac surgery patients and physical therapists } \\
\text { based on the results of patient surveys } \\
\text { National University of Ukraine } \\
\text { on Physical Education and Sport } \\
\text { GI «Scientific and Practical Medical Center } \\
\text { for Pediatric Cardiology and Cardiac Surgery } \\
\text { of the Ministry of Health of Ukraine» }\end{array}$ \\
\hline
\end{tabular}

\section{Зв'язок роботи 3 науковими програмами, планами, темами}

Роботу виконано згідно плану НДР НУФВСУ на 2016-2020 рр. за темою: «Організаційні та теоретикометодичні основи фізичної реабілітації осіб різних нозологічних, професійних та вікових груп», № державної реєстрації $0116 \mathrm{U} 001609$.

\section{Ветуп}

Специфічні та неспецифічні ефекти притаманні будь якому лікуванню чи терапії [1,2]. Неспецифічні ефекти пов'язані з відносинами пацієнта та терапевта, оточенням, характеристиками терапевта та задоволеністю пацієнтів [2]. Хоча клінічно специфічні та неспецифічні ефекти діють разом, кількісна оцінка неспецифічних ефектів не $\epsilon$ основним напрямком досліджень у реабілітації [3].

Терапевтичний альянс $є$ частиною терапевтичних відносин між пацієнтом та терапевтом, а також сприяє неспецифічним ефектам лікування [4,5]. Поняття терапевтичний альянс вперше з'явилося у сфері психотерапії. У психотерапії формування терапевтичного альянсу та його міцність у відносинах між пацієнтом i терапевтом пов'язані з кращими результатами лікування $[6,7]$. Конструктивний терапевтичний альянс випливає 3 теорії переносу, котра вперше була викладена 3. Фрейдом [8]. Теорія терапевтичного альянсу була розроблена Bordin E.S. [4]. Відповідно до цієї теорії, конструктивний терапевтичний альянс - це колоборативна особливість терапевтичних відносин, котра дає можливість пацієнту сумлінно приймати лікування та дотримуватися його [9].

Збільшується кількість даних про те, що у рамках реабілітації та фізичної терапії ця асоціація також існує
[10,11]. У реабілітації терапевтичний альянс також пов'язують 3 поліпшенням клінічних результатів [1]. Результати систематичних оглядів свідчать про те, що терапевтичний альянс не досліджувався в реабілітації та фізичній терапії систематично, оскільки відсутній консенсусу щодо підходів у його оцінці $[10,12,13]$.

Терапевтичний альянс включає три сфери: наявність узгоджених між пацієнтом і терапевтом цілей лікування; наявність узгоджених між пацієнтом та терапевтом завдань, котрі необхідні для досягнення цілей; якість зв'язку (взаємовідносин) між пацієнтом та терапевтом [4].

Попередні дослідження підкреслювали, що відносини пацієнт-терапевт є важливою концепцією, яка, як видається, впливає на ефекти лікування; однак дослідження Hall A.M. та співавторів показує [14], що важко виміряти цю концепцію в клінічних дослідженнях та практиці. Подальший розвиток цієї конструкції за допомогою фокус-груп та експертного висновку необхідний для повної оцінки конструкції, що лежить в основі взаємозв'язку пацієнт-терапевт у фізичній реабілітації.

Опитувальник Working Alliance Inventory (WAI) $\epsilon$ найпоширенішим інструментом для оцінки терапевтичного альянсу як в психотерапії, так і в фізичній терапії $[7,10,12] .3$ огляду на результати досліджень, WAI здається придатним як для клінічної практики, так і для досліджень $[1,15]$. WAI, а також інші інструменти, що вимірюють терапевтичний альянс, включають елементи, специфічні для лікування в психотерапії, наприклад, пункт «У результаті цих сесій я більш чітко розумію, як я можу змінитися» [16]. Залишається незрозумілим, чи справді представлена Бордіним конструкція терапевтичного союзу переноситься на фізичну терапію [12], хоча 
було висловлено припущення, що конструктивний терапевтичний альянс придатний для використання у багатьох терапевтичних сферах [4]. На наш погляд, навіть цей згаданий пункт опитувальника $\epsilon$ актуальним для фізичної терапії, адже в результаті занять фізичною терапією пацієнт може сформувати уявлення про зміни у його незалежності від сторонньої допомоги та адаптивних змін зовнішнього середовища, якості життя, активності повсякденного життя, діяльності та участі.

Наразі досліджень терапевтичного альянсу у сфері фізичної терапії не вистачає, а у напрямі фізичної терапії кардіохірургічних пацієнтів взагалі відсутні.

Мета - провести аналіз показників терапевтичного альянсу між кардіохірургічними пацієнтами та фізичними терапевтами за результатами анкетування пацієнтів.

\section{Матеріали та методи}

У опитуванні взяли участь 87 пацієнтів (старше 18 років, без когнітивних порушень), котрим виконувалось кардіохірургічне втручання. Усі учасники погодились взяти участь у дослідженні і самостійно заповнювали опитувальники. Допомога консультантів, котра була можливою за потреби, не використовувалася.

Для дослідження терапевтичного альянсу використаний опмитувальник WAI, а саме форма SF Hatcher Client (для пацієнта), котра включала 12 запитань [17]. Оцінка проводилася за 5-бальною шкалою: 5 завжди; 4 - дуже часто; 3 - досить часто; 2 - іноді; 1 рідко. Окрім того, питання були розділені на три групи/домени: «цілі», «завдання» та «взаємовідносини». Відповідно, кожен 3 цих доменів оцінювався від 4 (мінімум) до 20 балів (максимум), а загальний бал опитувальника від 12 (мінімум) до 60 (максимум) балів. Заповнення опитувальника відбувалося на сьомий післяопераційний день (ПОД).

Втручання. Перед операцією пацієнти отримували коротку консультацію фізичного терапевта щодо цілей та змісту ФТ, алгоритму активізації після операції. Післяопераційний протокол ФТ передбачав наступні особливості ранньої мобілізації пацієнта: сидіння на ліжку 3 опущеними ногами вниз у 1 ПОД; вертикалізацію (вставання 3 допомогою та під контролем фізичного терапевта 3 можливістю триматися руками за ходунок; узгоджується 3 анестезіологом) і ходьбу на місці за можливості у 1-2 ПОД; у 2 ПОД - ходьба на місці, ходьба палатою; на 3 ПОД - ходьба коридором; 4-5 ПОД - ходьба сходами. Окрім того пацієнти виконували терапевтичні вправи, техніки респіраторної фізичної терапії, лікувальну ходьбу під контролем фізичного терапевта. Для самостійного виконання - лікувальна ходьба, невеликий комплекс терапевтичних та дихальних вправ.

Заняття (біля 20 хвилин) з фізичним терапевтом проводилися 2 рази на день у 1 та 2 ПОД, 1-2 рази у 3 ПОД, 1 раз з 4 ПОД. За необхідності (стан пацієнта, необхідність мотивації) кількість та тривалість занять могла збільшуватися за рішенням фізичного терапевта.

Статистичний аналіз. Отримані результати були опрацьовані методами математичної статистики. Використовували прикладні програмами Statistica 7.0 та
IBM SPSS Statistics 21. Оскільки результати переважної більшості показників не відповідали закону нормального розподілу, розраховувалися медіана $(\mathrm{Me})$ та верхній i нижній квартилі $(25 \%$; 75\%). Для результатів показників, котрі відповідали закону нормального розподілу, розраховували середнє значення та середньоквадратичне відхилення $(\overline{\mathrm{x}} \pm \mathrm{S})$. Для порівнянні результатів доменів використовувався критерій U-критерій Манна-Уітні, оскільки вони мали розподіл відмінний від нормального. Окрім того, для більш детально розгляду результатів був використаний аналіз частот.

\section{Результати}

У дослідженні взяли участь 56 чоловіків та 31 жінка. Статистичні показники Ме $(25 \% ; 75 \%)$ для віку склали 64 (54;70) років. Середньостатистичні показники маси та довжини тіла на момент госпіталізації склали $82,75 \pm 15,38$ кг та $168,40 \pm 9,12$ см відповідно. Індекс маси

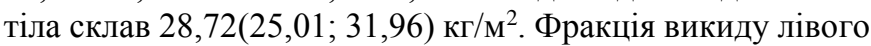
шлуночка серця - 53,5 $(47 ; 58,5) \%$. Тривалість операції становила 367,5 $(300 ; 436,5)$ хв, а наркозу $435(360 ; 506,3)$ хв. Штучна вентиляція легенів тривала $7,5(6 ; 11,25)$ год. Серед обстежених пацієнтів 4,6\% мали перший ступінь гіпертонічної хвороби, $37,9 \%$ та 36,8 - другий та третій відповідно. Функціональні класи NYHA мали наступні частки у вибірці: I - 13,8\%; II - 29,9\%; III - 56,3\%. Аортокоронарне шунтування виконувалося у 48 пацієнтів; втручання на мі тральному клапані у 35 ; на аортальному клапані у 38; трикуспідальному у 20; на аорті у 5 пацієнтів.

Розглянемо результати аналізу показників терапевтичного альянсу за даними опитувальників, котрі заповнювали кардіохірургічні пацієнти.

У першому пункті опитувальника (розуміння пацієнтом того, як він може змінитися у результаті занять) показники Ме $(25 \% ; 75 \%)$ становили 4(3; 5) бали. Значення $\mathrm{Me}(25 \% ; 75 \%)$ у другому пункті (частота отримання нових способів розгляду проблем пацієнта у результаті занять) склали $4(3 ; 4)$ бали. Третій пункт (пацієнт вважає, що він подобається фізичному терапевту) мав показники Me $(25 \% ; 75 \%)$ на рівні $3(2 ; 3)$ бали. Четвертий пункт опитувальника, котрий оцінюе співпрацю між фізичним терапевтом та пацієнтом над встановленням цілей терапії, отримав $4(3 ; 5)$ балів. У п'ятому пункті (взаємна повага між пацієнтом та фізичним терапевтом) показники $\operatorname{Me}(25 \% ; 75 \%)$ становили $5(4 ; 5)$ балів. Шостий пункт опитувальника (спільна праця фізичного терапевта та пацієнта у напрямку взаємно узгоджених цілей) був оцінений пацієнтами вибірки на рівні $5(4 ; 5)$ балів. У сьомому пункті опитувальника (відчуття у пацієнта того, що його цінує фізичний терапевт) оцінка була дещо нижчою, а показники Ме $(25 \% ; 75 \%)$ становили 4(3; 5) балів. Восьмий пункт опитувальника (спільне погодження фізичного терапевта та пацієнта у тому, що останньому треба працювати над собою) мав показники Ме $(25 \% ; 75 \%)$ на рівні $5(4 ; 5)$ балів. Дев'ятий пункт (пацієнт відчуває піклування зі сторони фізичного терапевта, навіть коли пацієнт робить те, що не схвалює фізичний терапевт), десятий (відчуття пацієнтом того, що заняття у фізичній терапії допоможуть виконати ті зміни, які він хоче) та 
одинадцятий (рівень встановлення гарного розуміння фізичним терапевтом та пацієнтом тих змін, які були б корисними для пацієнта) мали однакові показники $\operatorname{Me}(25 \% ; 75 \%)$ - 4(3;5) балів. Дванадцятий пункт опитувальника (оцінка частоти виникнення думки у пацієнта, що спосіб роботи з його проблемою правильний) мав показники на рівні $5(4 ; 5)$ балів.

Представлений аналіз частот (рис. 1) підтвердив, що більшість пацієнтів обирала відповіді з високим балом, тобто «дуже часто» та «часто». Лише у третьому пункті відповідь «іноді» відзначила найбільша частка пацієнтів.

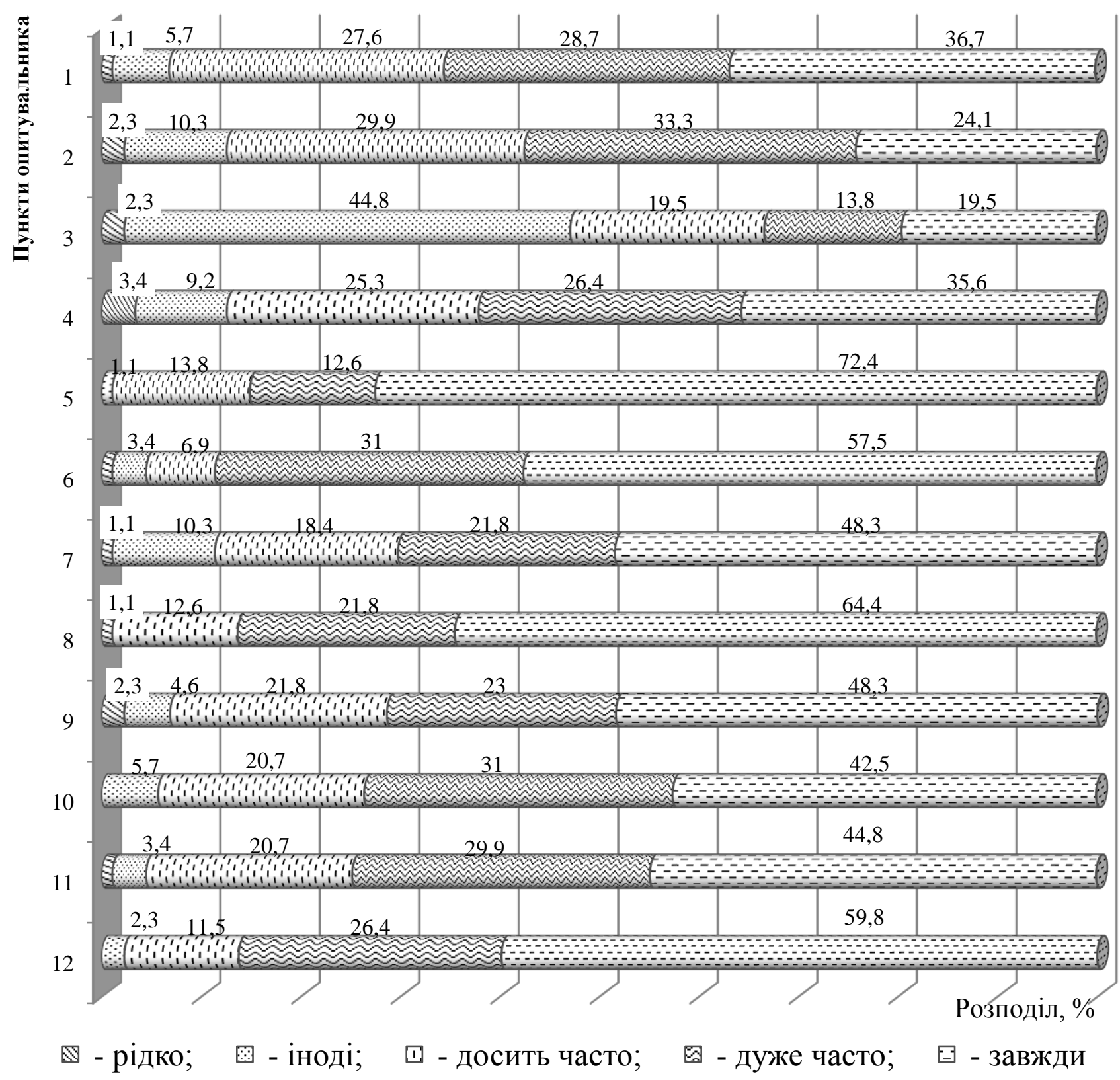

Пункти опитувальника: 1 - «У результаті цих сесій я більш чітко розумію, як я можу змінитися»; 2 - «Те, що я роблю в терапії, дає мені нові способи розгляду моєї проблеми»; 3 - «Я вважаю, що я подобаюсь ФТ»; 4 - «ФТ і я співпрацюю над встановленням цілей для моєї терапії»; 5 - «ФТ і я поважаємо один одного»; 6 - «ФТ і я працюю у напрямку взаємно узгоджених цілей»; 7 - «Я відчуваю, що ФТ цінує мене»; 8 - «ФТ і я згодні з тим, що для мене важливо працювати над собою»; 9 - «Я відчуваю, що ФТ піклується про мене, навіть коли я роблю те, що він/вона не схвалює»; 10 - «Я відчуваю, що те, що я роблю в терапії, допоможе мені виконати ті зміни, які я хочу»; 11 - ФТ і я встановили гарне розуміння тих змін, які були б корисними для мене»; 12 - «Я вважаю, що спосіб роботи з моєю проблемою правильний»; ФТ фізичний терапевт.

Рис. 1. Розподіл відповідей пацієнтів щодо формування терапевтичного альянсу 
Серед кардіохірургічних пацієнтів показники Me (25\%;75\%) загальної оцінка пунктів «ціль» становили $17(15 ; 20)$ балів. Показники Ме $(25 \% ; 75 \%)$ загальної оцінки пунктів «завдання» склали $18(16 ; 18)$ балів, а загальної оцінки пунктів «взаємовідносин» - $16(13 ; 18)$ балів. Значення $\overline{\mathrm{x}} \pm \mathrm{S}$ цих трьох показників відповідно склали $16,84 \pm 2,81$ бала, $16,71 \pm 5,97$ бала та $15,75 \pm 3,10$ бала.
Слід наголосити, що оцінка проводилася за 5бальною шкалою, котра починалася з 1 балу, а не 0 . Це необхідно враховувати при аналізі та інтерпретації результатів, зокрема при порівнянні отриманих балів та максимально можливих. 3 врахуванням цього були розраховані частки від теоретичного максимуму за трьома доменами (рис. 2).

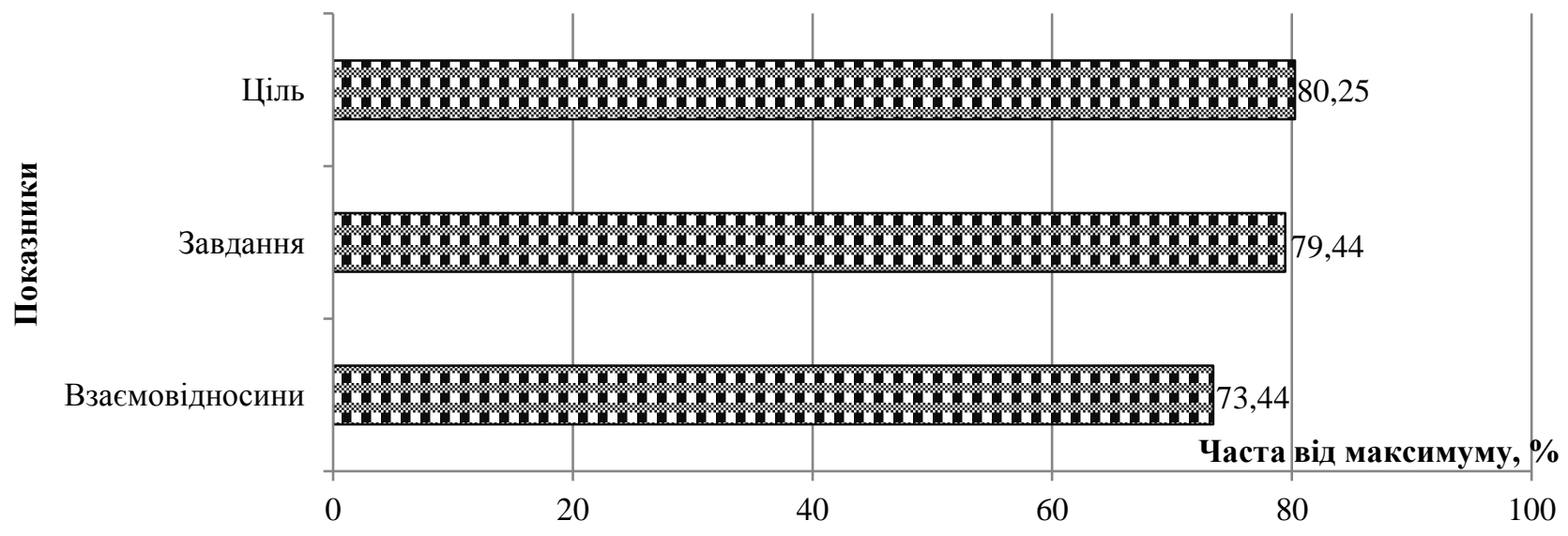

Рис. 2. Відносні показники загальних оцінок/доменів терапевтичного альянсу

Загальний показник всього опитувальника склав 50 $(43 ; 55)$ балів, а значення $\overline{\mathrm{X}} \pm \mathrm{S}$ склали $49,31 \pm 9,02$ бала, що склало 77,7\% від максимуму з врахуванням особливостей оцінки (оцінювання починається з 1 балу).

\section{Дискусія}

Результати оцінки терапевтичного альянсу між кардіохірургічними пацієнтами та фізичними терапевтами підтвердили досить високий його рівень, незважаючи на особливості такої фізичної терапії та тривалість періоду для формування відносин. Зокрема, умови та час втручання фізичного терапевта $є$ досить емоційно та фізично важкими для пацієнта. Водночас, суб'єктивна важкість процедур, особливо перших, може варіюватися залежно від особливостей відновлення пацієнта після ряду факторів, котрі діяли під час операції (зокрема наркоз). Тому певна частка пацієнтів може вважати процедуру фізичної терапії чи завдання, котрі необхідно виконати (сісти, встати, ходьба), дещо важкими.

Серед розглянутих пунктів опитувальника третій мав найнижчий бал, оскільки відповідь «іноді» у цьому пункті була встановлена у 44,8\% опитувальників, а частка, котра припадала на відповіді «досить часто», «дуже часто» та «часто» була меншою ніж у інших пунктах опитувальника. Найбільшу частку відповідей 3 максимальними 5 балами отримано у п'ятому пункті опитувальника. Цікаво, що третій та п'ятий пункти відносяться до домену «взаємовідносини». Відповідно видається дещо незрозумілим ця діагональна протилежність у результатах. Можливою причиною цього $€$ заниження самими пацієнтами оцінки у третьому пункті 3 причини невдоволенням своїм станом чи зовнішнім виглядом («як я можу комусь подобатись?», «що тут може подобатися? Старий... Слабкий...»).

Відзначимо, що показники доменів «ціль» та «відношення» ( $\mathrm{p}=0,019)$ достовірно відрізнялися, а при порівнянні пар доменів «ціль» та «завдання» $(\mathrm{p}=0,141)$, «завдання» та «відношення» $(\mathrm{p}=0,416)$ статистичних відмінностей не встановлено.

Ми не змогли знайти робіт присвячених дослідженню терапевтичного альянсу між фізичними терапевтами та пацієнтами, котрі перенесли кардіохірургічне втручання, у рамках проходження як стаціонарної так і амбулаторної програми фізичної терапії.

Це дає підстави констатувати, що представлені результати є першими 3 тих, котрі оцінюють рівень формування терапевтичного альянсу в умовах кардіохірургічного стаціонару між фізичним терапевтом та пацієнтом.

Автори більшості попередніх робіт досліджували фактори, котрі впливають на формування терапевтичного альянсу між фізичним терапевтом та пацієнтом, а також зв'язок між рівнем терапевтичного альянсу та результативністю фізичної терапії. Слід відзначити, що більшість досліджень терапевтичного альянсу у сфері фізичної терапії присвячена роботі з пацієнтами, котрі мають м'язово-скелетні порушення.

Попередні дослідження, котрі використовували WAI для оцінки терапевтичного альянсу у сфері фізичної терапії також підтвердили досить високий його рівень.

Зокрема терапевтичний альянс між фізичним терапевтом та пацієнтом, котрий досліджувався у рамках амбулаторної програми фізичної терапії, мав кращі показники у пацієнтів 3 раціональним відношенням до хвороби [18]. Так, оцінка домену «ціль» була достовірно 
кращою у пацієнтів 3 раціональними психотипами 14 $(12,75 ; 15)$ балів проти $12(11 ; 14)$ балів серед пацієнтів 3 нераціональними психотипами. Аналогічно оцінка домену «завдання» становила $15(13 ; 15)$ балів проти $12(11 ; 15)$ балів, а домену «взаємовідносини» - 16 (16;17) балів проти $14(13 ; 15)$ балів.

Наші показники видаються дещо більшими. Окрім того, тенденція у балах доменів мала протилежний напрямок. У нашому дослідженні бали дещо знижувались у напрямку «ціль»-«завдання»-«ціль», а у згаданому дослідженні [18], навпаки, зростали.

\section{Висновки}

Проведений аналіз оцінок терапевтичного альянсу між кардіохірургічними пацієнтами та фізичними терапевтами за результатами анкетування пацієнтів підтвердив досить високий його рівень. Показники Me $(25 \% ; 75 \%)$ доменах терапевтичного альянсу становили: $17(15 ; 20)$ балів у домені «ціль», $18(16 ; 18)$ балів у домені «завдання», а загальної у домені «взаємовідносин» - $16(13 ; 18)$ балів. Середні значення цих доменів склали відповідно 80,25\%, 79,44\% та 73,44\% від максимальної оцінки (з врахуванням особливостей шкали оцінювання).

\section{Література}

1. Paap D., Schrier E., Dijkstra P. U. Development and validation of the Working Alliance Inventory Dutch version for use in rehabilitation setting. Physiotherapy theory and practice. 2019. Vol. 35(12). P. 1292-1303.

2. Crow R., Gage H., Hampson S., Hart J., Kimber A., Thomas H. The role of expectancies in the placebo effect and their use in the delivery of health care: a systematic review. Health Technology Assessment. 1999. Vol. 3. P. 1-96.

3. Fuentes J., Armijo-Olivo S., Funabashi M., Miciak M., Dick B., Warren S., Gross D.P. Enhanced therapeutic alliance modulates pain intensity and muscle pain sensitivity in patients with chronic low back pain: An experimental controlled study. Physical Therapy. 2014. Vol. 94. P. 477-489.

4. Bordin E.S. The generalizability of the psychoanalytic concept of the working alliance. Psychotherapy: Theory, Research and Practice. 1979. Vol.16. P. 252-260.

5. Greenberg L.S., Webster M.C. Resolving decisional conflict by Gestalt two-chair dialogue: Relating process to outcome. Journal of Counseling Psychology. 1982. Vol.29. P. 468-477.

6. Del Re A., Flückiger C., Horvath A.O., Symonds D., Wampold B.E. Therapist effects in the therapeutic allianceoutcome relationship: A restricted-maximum likelihood metaanalysis. Clinical Psychology Review. 2012. Vol.32. P. 642-649.

7. Horvath A.O., Del Re A., Flückiger C., Symonds D. Alliance in individual psychotherapy. Psychotherapy. 2011. Vol.48. P. 9-16.

8. Freud S. On Beginning the Treatment (Further Recommendations on the Technique of Psy cho-Analy sis I). The Standard Edition of the CompletePsy chological Works of Sigmund Freud, Volume XII (1911-1913): The Case of Schreber, Papers on Technique and Other Works. 1913. P. 121-144.

9. Bordin E.S. Theory and Research on the Therapeutic Working Alliance: new Directions. In: Irving B. Weiner (Series ed). The Working Alliance: theory, Research, and Practice. New York: Wiley, 1994. P. 13-37.

10. Hall A.M., Ferreira P.H., Maher C.G., Latimer J., Ferreira M.L. The influence of the therapist-patient relationship on treatment outcome in physical rehabilitation: A systematic review. Physical Therapy. 2010. Vol.90. P. 1099-1110.

11. Lakke S.E., Meerman S. Does working alliance have an influence on pain and physical functioning in patients with chronic musculoskeletal pain; A systematic review. Journal of Compassionate Health Care. 2016. Vol.3. P. 1-10.

12. Babatunde F., MacDermid J., MacIntyre N. Characteristics of therapeutic alliance in musculoskeletal physiotherapy and occupational therapy practice: A scoping review of the literature. BMC Health Services Research. 2017. Vol.17. P. 375.

13. Besley J., Kayes N.M., McPherson K.M. Assessing therapeutic relationships in Physiotherapy: Literature review. New Zealand Journal of Physiotherapy. 2010. Vol. 39. P: 81-91.

14. Hall A.M., Ferreira M.L., Clemson L., Ferreira P., Latimer J., Maher C.G. Assessment of the therapeutic alliance in physical rehabilitation: a RASCH analysis. Disability and rehabilitation. 2012. Vol.34(3). P. 257-266.

15. Elvins R., Green J. The conceptualization and measurement of therapeutic alliance: An empirical review. Clinical Psychology Review. 2008. Vol.28. P. 1167-1187.

16. Horvath A.O., Greenberg L.S. Development and validation of the Working Alliance Inventory. Journal of Counseling Psychology. 1989. Vol.36. P.223-233.

17. Hatcher R. L., Gillaspy J. A. Development and validation of a revised short version of the Working Alliance Inventory. Psychotherapy research. 2006. Vol.16(1). P. 12-25.

18. Fedorenko S.M., Vitomskyi V.V., Lazarieva O.B., Vitomska M.V. The results of the analysis of the criteria of therapeutic alliance of patients orthopedic profile of outpatient physical therapy program. Health, sport, rehabilitation. 2019. Vol.5(3). P. 15-23. DOI: https://doi.org/10.34142/HSR.2019.05.03.02. 


\section{References}

1. Paap D, Schrier E, Dijkstra PU. Development and validation of the Working Alliance Inventory Dutch version for use in rehabilitation setting. Physiotherapy theory and practice. 2019; 35(12):1292-303.

2. Crow R, Gage H, Hampson S, Hart J, Kimber A, Thomas H. The role of expectancies in the placebo effect and their use in the delivery of health care: a systematic review. Health Technology Assessment. 1999;3:1-96.

3. Fuentes J, Armijo-Olivo S, Funabashi M, Miciak M, Dick B, Warren S, Gross DP. Enhanced therapeutic alliance modulates pain intensity and muscle pain sensitivity in patients with chronic low back pain: An experimental controlled study. Physical Therapy. 2014;94:477-89.

4. Bordin ES. The generalizability of the psychoanalytic concept of the working alliance. Psychotherapy: Theory, Research and Practice. 1979;16:252-60.

5. Greenberg LS, Webster MC. Resolving decisional conflict by Gestalt two-chair dialogue: Relating process to outcome. Journal of Counseling Psychology. 1982;29:468-77.

6. Del Re A, Flückiger C, Horvath AO, Symonds D, Wampold BE. Therapist effects in the therapeutic allianceoutcome relationship: A restricted-maximum likelihood metaanalysis. Clinical Psychology Review. 2012;32:642-9.

7. Horvath AO, Del Re A, Flückiger C, Symonds D. Alliance in individual psychotherapy. Psychotherapy. 2011; 48:9-16.

8. Freud S. On Beginning the Treatment (Further Recommendations on the Technique of Psy cho-Analy sis I). The Standard Edition of the CompletePsy chological Works of Sigmund Freud, Volume XII (1911-1913): The Case of Schreber, Papers on Technique and Other Works. 1913. 121-144.

9. Bordin ES. Theory and Research on the Therapeutic Working Alliance: new Directions. In: Irving B. Weiner (Series ed). The Working Alliance: theory, Research, and Practice. New York: Wiley, 1994. 13-37.

10. Hall AM, Ferreira PH, Maher CG, Latimer J, Ferreira ML. The influence of the therapist-patient relationship on treatment outcome in physical rehabilitation: A systematic review. Physical Therapy. 2010;90:1099-110.

11. Lakke SE, Meerman S. Does working alliance have an influence on pain and physical functioning in patients with chronic musculoskeletal pain; A systematic review. Journal of Compassionate Health Care. 2016;3: 1-10.

12. Babatunde F, MacDermid J, MacIntyre N. Characteristics of therapeutic alliance in musculoskeletal physiotherapy and occupational therapy practice: A scoping review of the literature. BMC Health Services Research. 2017;17:375.

13. Besley J, Kayes NM, McPherson KM. Assessing therapeutic relationships in Physiotherapy: Literature review. New Zealand Journal of Physiotherapy. 2010;39:81-91.

14. Hall AM, Ferreira ML, Clemson L, Ferreira P, Latimer J, Maher CG. Assessment of the therapeutic alliance in physical rehabilitation: a RASCH analysis. Disability and rehabilitation. 2012; 34(3):257-66.

15. Elvins R, Green J. The conceptualization and measurement of therapeutic alliance: An empirical review. Clinical Psychology Review. 2008;28:1167-87.

16. Horvath AO, Greenberg LS. Development and validation of the Working Alliance Inventory. Journal of Counseling Psychology. 1989;36:223-33.

17. Hatcher RL, Gillaspy JA. Development and validation of a revised short version of the Working Alliance Inventory. Psychotherapy research. 2006;16(1):12-25.

18. Fedorenko SM, Vitomskyi VV, Lazarieva OB, Vitomska MV. The results of the analysis of the criteria of therapeutic alliance of patients orthopedic profile of outpatient physical therapy program. Health, sport, rehabilitation. 2019;5(3):15-23. DOI: https://doi.org/10.34142/HSR.2019.05.03.02.

Дата надходження рукопису до редакції: 14.07.2020 p.

Мета - провести аналіз показників терапевтичного альянсу між кардіохірургічними пацієнтами та фізичними терапевтами за результатами анкетування пацієнтів.

Матеріали та методи. У опитуванні взяли участь 87 пацієнтів (старше 18 років, без когнітивних порушень), котрим виконувалось кардіохірургічне втручання. Для дослідження терапевтичного альянсу використаний опитувальник Working Alliance Inventory, а саме форма SF Hatcher Client (для пацієнта), котра включала 12 запитань. Оцінка проводилася за 5-бальною шкалою (від 1 до 5 балів). Заповнення опитувальника відбувалося на сьомий післяопераційний день.

Результати. Проведений аналіз частот підтвердив, що більшість пацієнтів обирала відповіді 3 високим балом, тобто «дуже часто» та «часто», у всіх крім одного пунктах опитувальника. Показники Ме $(25 \% ; 75 \%)$ у доменах терапевтичного альянсу становили: $17(15 ; 20)$ балів у домені «ціль», $18(16 ; 18)$ балів у домені «завдання», а у домені «взаємовідносини» - $16(13 ; 18)$ балів. Середні значення цих доменів склали відповідно 80,25\%, 79,44\% та 73,44\% від максимальної оцінки (з врахуванням особливостей шкали оцінювання). Відзначимо, що показники доменів «ціль» та «відношення» ( $=0,019)$ достовірно відрізнялися, а при порівнянні пар доменів «ціль» та «завдання» ( «завдання» та «відношення» $(\mathrm{p}=0,416)$ статистичних відмінностей не встановлено. Загальний показник всього 


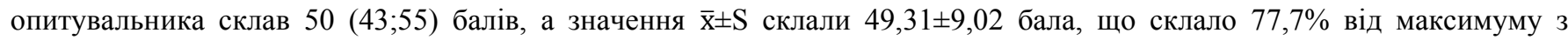
врахуванням особливостей оцінки.

Висновки. Проведений аналіз оцінок терапевтичного альянсу між кардіохірургічними пацієнтами та фізичними терапевтами за результатами анкетування пацієнтів підтвердив досить високий його рівень.

Ключові слова: робочий альянс, союз, розуміння, емпатія, фізична реабілітація, терапевтичні вправи, якість.

Цель: провести анализ показателей терапевтического альянса между кардиохирургическими пациентами и физическими терапевтами по результатам анкетирования пациентов.

Материалы и методы. В опросе приняли участие 87 пациентов (старше 18 лет, без когнитивных нарушений), которым выполнялось кардиохирургическое вмешательство. Для исследования терапевтического альянса использован опросник Working Alliance Inventory, а именно форма SF Hatcher Client (для пациента), которая включала 12 вопросов. Оценка проводилась по 5-балльной шкале (от 1 до 5 баллов). Заполнение опросника происходило на седьмой послеоперационный день.

Результаты. Проведенный анализ частот подтвердил, что большинство пациентов выбирали ответы с высоким баллом, то есть «очень часто» и «часто», во всех кроме одного пунктах опросника. Показатели Ме (25\%; $75 \%)$ в доменах терапевтического альянса составляли: $17(15,20)$ баллов в домене «цель», $18(16,18)$ баллов в домене «задачи», а в домене «взаимоотношения» $16(13,18)$ баллов. Средние значения этих доменов составили соответственно 80,25\%, $79,44 \%$ и 73,44\% от максимальной оценки (с учетом особенностей шкалы оценивания). Отметим, что показатели доменов «цель» и «отношения» $(\mathrm{p}=0,019)$ достоверно отличались, а при сравнении пар доменов «цель» и «задача» $(\mathrm{p}=0,141)$, «задача» и «отношения» $(\mathrm{p}=0,416)$ статистических различий не установлено.

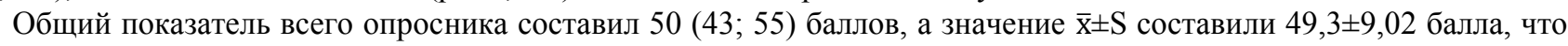
составило 77,7\% от максимума с учетом особенностей оценки.

Выводы. Проведенный анализ оценок терапевтического альянса между кардиохирургическими пациентами и физическими терапевтами по результатам анкетирования пациентов подтвердил достаточно высокий его уровень.

Ключевые слова: рабочий альянс, союз, понимание, эмпатия, физическая реабилитация, терапевтические упражнения, качество.

Purpose: to analyze the indicators of the therapeutic alliance between cardiac surgery patients and physical therapists based on the results of patient surveys.

Materials and methods. The survey involved 87 patients (over 18 years of age, without cognitive impairment) who underwent cardiac surgery. The Working Alliance Inventory was used to study the therapeutic alliance, namely the SF Hatcher Client form (for the patient), which included 12 questions. The assessment was performed on a 5-point scale (1 to 5 points). The questionnaire was completed on the seventh postoperative day.

Results. The frequency analysis confirmed that the majority of patients chose answers with a high score, ie "very often" and "often", in all but one questionnaire. Me indicators $(25 \% ; 75 \%)$ in the domains of the therapeutic alliance were: $17(15 ; 20)$ points in the domain "goal", $18(16 ; 18)$ points in the domain "task", and in the domain "bond" - 16 $(13 ; 18)$ points. The average values of these domains were $80.25 \%, 79.44 \%$ and $73.44 \%$ of the maximum score, respectively (taking into account the peculiarities of the rating scale). Note that the indicators of the domains "goal" and "bond" $(\mathrm{p}=0.019)$ differed significantly, and when comparing pairs of domains "goal" and "task" ( $p=0.141)$, "task" and " bond" $(\mathrm{p}=0.416)$ no statistical differences were found.

The total score of the entire questionnaire was $50(43 ; 55)$ points, and the values of $\bar{x} \pm S$ were $49.31 \pm 9.02$ points, which was $77.7 \%$ of the maximum, taking into account the peculiarities of the assessment.

Conclusions. The analysis of the assessments of the therapeutic alliance between cardiac surgery patients and physical therapists based on the results of the patient survey confirmed its rather high level.

Key words: working alliance, union, understanding, empathy, physical rehabilitation, therapeutic exercises, quality.

\section{Відомості про автора}

Вітомський Володимир Вікторович - кандидат наук з фізичного виховання та спорту, викладач кафедри фізичної терапії та ерготерапії, Національний університет фізичного виховання і спорту України; фахівець 3 фізичної реабілітації, ДУ «Науково-практичний медичний центр дитячої кардіології та кардіохірургії МОЗ України». vitomskiyvova@gmail.com, ORCID ID 0000-0002-4582-6004. 